\title{
Case Report: Epstein-Barr-Virus negative diffuse large B-cell lymphoma detected in a peri-prosthetic membrane
}

\author{
Sandra Sunitsch¹, Magdalena Gilg², Karl Kashofer ${ }^{1}$, Andreas Leithner ${ }^{2}$, Bernadette Liegl-Atzwanger ${ }^{1 *}$ \\ and Christine Beham-Schmid ${ }^{1}$
}

\begin{abstract}
Background: Primary bone lymphomas (PBL) are extremely rare malignant neoplasms. The most commonly described subtype of PBL is diffuse large B-cell lymphoma (DLBCL). DLBCL within peri-prosthetic membrane of a joint is exceedingly rare. To the best of our knowledge this case is the second reported Epstein-Bar-Virus (EBV) negative DLBCL in a peri-prosthetic membrane in the literature.
\end{abstract}

Case presentation: We report an 80 year old female patient who developed a DLBCL with chronic inflammation in association to a metallic implant in the left knee. This lymphoma in contrast to the usually described DLBCL in the periprosthetic membrane was EBV negative by EBER in situ hybridization as well as by polymerase chain reaction (PCR).

Conclusion: This report challenges the concept of $D L B C L$ associated with chronic inflammation and raises the question of other pathogenetic factors involved in the pathogenesis of this rare disease.

Keywords: Primary bone lymphoma, Diffuse large B-cell lymphoma, Epstein-Barr-Virus negative, Knee arthroplasty, Periprosthetic membrane

Abbreviations: ASA, American Society of Anesthesiology Classification; DLBCL, Diffuse large B-cell lymphoma; EBV, Epstein- Bar-Virus; Gy, Gray; HBV DNA, Hepatitis B Virus Deoxyribonucleic acid; HBVc, Hepatitis B Virus core; HBx, HBV-encoded X-protein; NGS, Next generation sequencing; NHL, Non-Hodgkin Lymphoma; PBL, Primary bone lymphoma; PCR, Polymerase chain reaction; WHO, World Health Organization

\section{Background}

Lymphoma is the seventh most common systemic malignancy worldwide $[1,2]$. DLBCL is the most common aggressive Non-Hodgkin Lymphoma (NHL) [3] and in addition the most common type of PBL [4]. Over the last decades, the use of joint replacement surgery, such as total hip and total knee arthroplasty, has increased [2]. Despite this fact lymphomas developed within the peri-prosthetic membrane are exceedingly rare. These lymphomas may be observed in a context of chronic inflammation with EBV, which seems to play a central role in disease development. Since 2008 this entity has been included in the World Health Organization (WHO)

\footnotetext{
* Correspondence: bernadette.liegl-atzwanger@medunigraz.at ${ }^{1}$ Institute of Pathology, Medical University of Graz, Graz, Austria Full list of author information is available at the end of the article
}

classification of Haematopoietic and Lymphoid Tissues as "DLBCL associated with chronic inflammation" $[1,5]$.

\section{Case presentation}

In 2004 a 69 year old woman underwent total left knee replacement with a cemented knee endoprosthesis for osteoarthritis. In February 2015 a loosening of the prosthesis was diagnosed radiologically (Fig. 1) in association with a rupture of the collateral ligament.

The patient underwent replacement of the prosthesis in August 2015 with ASA 4 (American Society of Anesthesiology Classification) because of multiple comorbidities. The listed comorbidities included adipositas, diabetes mellitus, high blood pressure, hyperlipidaemia and coronary heart disease. In addition the patient showed in clinical chemistry positivity for HBVc (Hepatitis B Virus core) antibody but negativity for Hepatitis B by PCR. 


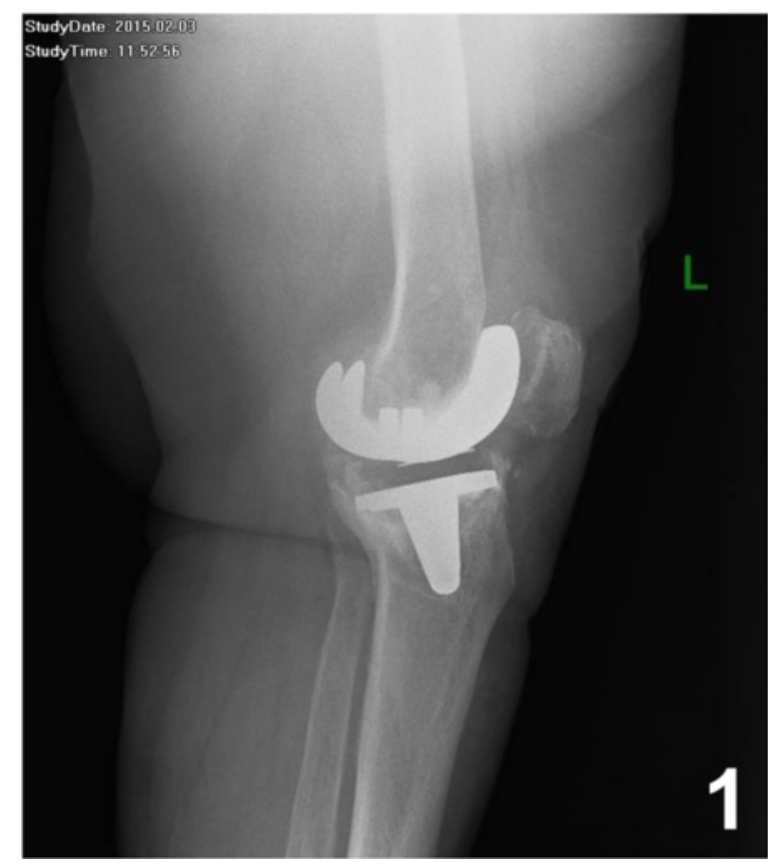

Fig. 1 Radiography of the left knee shows a loosening of the prosthesis

The peri-prosthetic membrane was removed and a new prosthesis was implanted without complications. The peri-prosthetic membrane was sent to the Institute of Pathology to exclude infection. The histological examination showed infiltration by a DLBCL. Clinically the patient showed no signs of generalization.

A chemotherapy with (R-)-mini-CHOP (with $50 \%$ of Cyclophospamid, Doxorubicin and Oncovin) was started. Because of the positivity of HBVc antibody the Mabthera therapy started in the 2nd cycle after confirmation of negative Hepatitis B PCR. After chemotherapy she received a total irradiation dose 40 Gy with conventional fractions.

At a follow-up of 8 months the patient did not show any sign of recurrence.

\section{Results}

The specimen sent for histological examination measured 2:1,5:0,8 $\mathrm{cm}$ and revealed grey-white tissue.

The histolologic examination showed connective tissue with massive hyalinization and sclerosis with a centrally, circumscribed, nodular infiltration of large lymphoid cells (Fig. 2a). The predominant cellular component consisted of blasts, with round and notched nuclei with clear chromatin and multiple nucleoli (Fig. 2b). The mitotic activity was high with 4 mitoses per high power field. Between the blasts a few polymorphic small reactive lymphocytes were present. The blasts showed strong expression of CD 20, CD 79a (Fig. 2c), CD20 (Fig. 2d), PAX 5 and bcl-2 by immunohistochemistry.
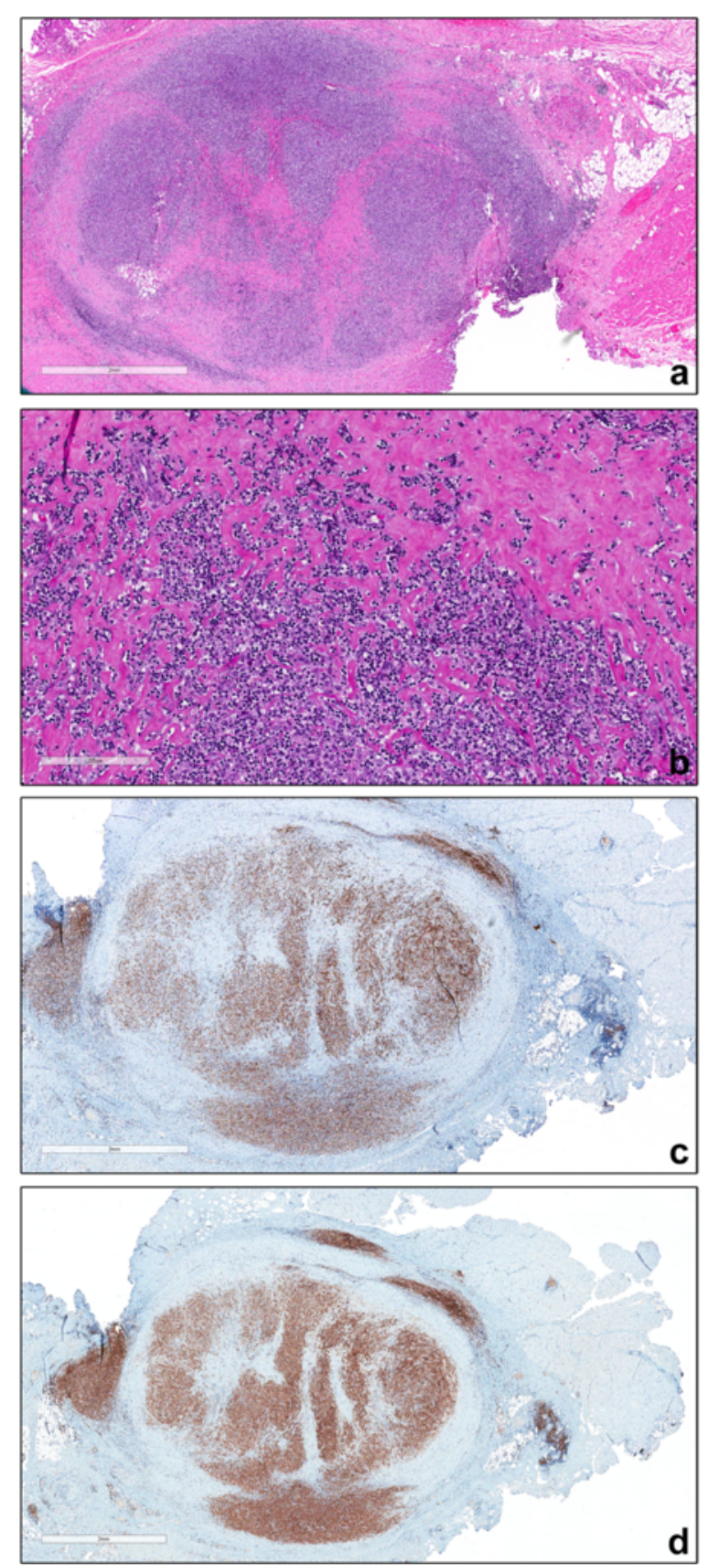

Fig. 2 a HE stained section shows connective tissue with massive hyalinization and sclerosis and skeletal muscle with a centrally, circumscribed, nodular infiltration of large lymphoid cells. b The predominant cellular component consisted of blasts, with round and notched nuclei with clear chromatin and multiple nucleoli. c In the immunohistochemistry staining the blasts reveal an expression of CD 79a. $\mathbf{d}$ In the immunohistochemistry staining the blasts reveal an expression of CD 20

Only a small subset of blasts demonstrated a positive staining with CD 30 and bcl-6 (<5\%). Staining for EBER (in situ hybridisation for EBV with INFORM EBER) and CD 15 were negative. In addition the atypical B-cell 
population did not express CD10, MUM1, GCET1, CD33, myeloperoxidase, C-MYC, CD117c and FOXP1. The proliferation index (MIB) was $80 \%$.

The diagnosis of a DLBCL was supported by performing a PCR, demonstrating a gene rearrangement in the immunoglobulin heavy chain gene with a monoclonal peak at $243 \mathrm{bp}$ and an immunoglobulin light chain gene rearrangement with a monoclonal cell population kappa A at $288 \mathrm{bp}$.

EBV was additionally excluded by a PCR using Lightcycler analysis.

Performing a Low Density Whole Genome Copy Number Variation with next generation sequencing (NGS) we could not detect any copy number variation. Furthermore mutational analysis of the full coding sequence of the TP 53 gene did not demonstrate mutations in TP 53.

\section{Discussion}

Primary lymphoma of the bone is rare, accounting for 3-7 \% of malignant bone neoplasms and $4-5 \%$ of extranodal Non-Hodgkin lymphomas [6]. Primary NonHodgkin lymphomas arising in the peri-prosthetic membrane around metallic implants are extremely rare. The carcinogenic effects of the metallic components and wear particles are not yet fully elucidated [7]. Most cases reported in this context are DLBCL associated with chronic inflammation and concomitant EBV infection $[2,7]$. Campo et al. report, that in these lesions lymphomas-infected cells frequently express a latency type 3 with positivity for the viral proteins latent membrane protein 1 and EBV nuclear antigen 2, suggesting, that the lymphoid proliferation may be related primarily to a decrease in the host immune-surveillance [5]. Our described case of DLBCL, however, lacks EBV infection and is localized to the knee without any other site of involvement. A summary of our literature search (see Table 1) showed only one case of diffuse large B-cell lymphoma in association with a joint replacement without EBV association and was published in 2011 [2]. Another case was reported with negativity for the EBV in situ hybridization, but positivity for EBV in the polymerase chain reaction [7]. All reported cases did not show any signs of generalization [2, 7-13].

In the context of our case we would like to challenge the concept that "DLBCL associated with chronic inflammation" is always associated with EBV infection. In our case EBV could clearly not be demonstrated by otherwise classic features of "DLBCL associated with chronic inflammation". Although the pathogenesis in our case is not fully elucidated, we hypothesize that other factors may play a role in this context. Especially metallic ions are known to have carcinogenic potential. After a metal implantation a significant increased concentration of cobalt and chromium in the synovial fluid and blood could be measured. These metallic ions have mutagenic effects and have been described to potentially predispose to lymphomas [2]. In 2004 Landon et al. report about an increase in chromium and cobalt levels, an increased incidence of chromosomal translocation and an aneuploidy in the peripheral blood of patients within 2 years after metalon-metal joint arthroplasty [14].

In addition a higher level of HBVc antibody was incidentally found in our patient. Gross et al. states that

Table 1 Shows a summary of presented cases in the literature including our recent case

\begin{tabular}{|c|c|c|c|c|c|}
\hline Journal & Age/Sex & Localisation & Latency & Diagnosis & EBV status \\
\hline Our case & 80 female & Left knee & 11 years & $\mathrm{DLBCL}$ & EBERinsitu -PCR - \\
\hline $\begin{array}{l}\text { Acta Haematol. } \\
\text { 2011;126(3):141-6. [2] }\end{array}$ & 76 male & Right Tibia & 3 years & DLBCL & EBERinsitu - \\
\hline $\begin{array}{l}\text { Am J Surg Pathol 2005; } \\
\text { 29: 832-836. [8] }\end{array}$ & 78 male & Right knee & 22 years & $\mathrm{DLBCL}$ & EBV IHC + EBERinsitu + \\
\hline $\begin{array}{l}\text { Journal of Clinical Oncology, } \\
\text { Vol 31, 2013: pp e148-e151. [7] }\end{array}$ & 69 male & Left knee & 3 years & DLBCL & EBERinsitu - PCR + \\
\hline $\begin{array}{l}\text { Arch Orthop Trauma Surg } \\
\text { 2008; 128: 1387-1390. [9] }\end{array}$ & 70 female & Left knee & About a half year & $\mathrm{DLBCL}$ & not available \\
\hline $\begin{array}{l}\text { J Arthroplasty. } 2001 \\
\text { Feb;16(2):229-32. [10] }\end{array}$ & 97 female & Left hip & 12 years & $\begin{array}{l}\text { High-grade Non-Hodgkin's } \\
\text { B-cell lymphoma }\end{array}$ & not available \\
\hline $\begin{array}{l}\text { J Arthroplasty. } 2006 \\
\text { Sep;21(6):926-30. [11] }\end{array}$ & 75 female & Right tigh & 13 years & $\begin{array}{l}\text { Malignant immunoblastic } \\
\text { lymphoma }\end{array}$ & not available \\
\hline \multirow[t]{2}{*}{$\begin{array}{l}\text { J Clin Pathol. } 1998 \\
\text { Aug; 51(8): 629-632. [12] }\end{array}$} & 63 female & Left tigh & 4 years & $\begin{array}{l}\text { Diffuse centroblastic } \\
\text { lymphoma }\end{array}$ & not available \\
\hline & 25 male & Right tibia & 8 years & $\begin{array}{l}\text { Diffuse centroblastic } \\
\text { lymphoma }\end{array}$ & not available \\
\hline $\begin{array}{l}\text { Cancer. } 1981 \\
\text { Aug 15;48(4):1009-11. [13] }\end{array}$ & 48 male & Left tibia & 17 years & Malignant lymphoma & not available \\
\hline
\end{tabular}


a negative HBV DNA does not rule out an HBV infection [15].

In the literature a connection between Hepatitis B virus infection and Non-Hodgkin lymphomas is described [16-21]. It is suggested that HBV is not only a hepatotropic but also a lymphotropic disease and participates in the development of malignant lymphoproliferative disorders. For viral clearance the cellular and humoral immunity plays an important role for $\mathrm{HBV}$ infection and disease progression. The cellular and humoral immunity system gets activated after HBV infection. The immune system destroys the HBV infected cells and the host cells, which are infected by HBV [18]. However, the mechanisms are not fully elucidated [19, 20] and several theories are suggested. Proposed theories include [19]:

(a) Chronic stimulation of B-cells is the problem for DNA damage and transformation into B- cell NHL.

(b)Chronic local antigenic stimulation could be associated with a development of lymphoma.

(c) HBV-encoded X-protein (HBx) inhibits p53 in hepatocytes and this mechanism causes hepatocellular carcinoma. The inhibition of p53 in B-cells may cause malignant transformation into a NHL. However this theory can be excluded by performing mutational analysis covering the whole coding sequence of TP53.

(d)The infection of epithelial cells might serve as a trigger for expression, production or release of hematopoietic tumor growth factor.

(e) A coinfection with another unknown virus is suggested to cause lymphoma.

\section{Conclusion}

We report a case of an 80 year old woman, who developed an EBV negative DLBCL in the peri-prosthetic membrane 11 years after total knee arthroplasty. The presented case demonstrates that EBV infection might not be obligatory in DLBCL associated with chronic inflammation. This report challenges the concept of DLBCL associated with chronic inflammation and raises the question of other pathogenetic factors involved in the pathogenesis of this rare disease.

\section{Acknowledgment}

We thank the patient, who requested anonymity, for agreeing to our report and for providing a detailed medical history.

\section{Funding}

No funding has been gained by the authors for this research

\section{Availability of data and materials}

The dataset supporting the conclusions of this article is included within the article.

\section{Authors' contributions}

CBS, BLA and SS participated in the design of the study and

histopathological evaluation, and drafted the manuscript. KK and MG assisted in drafting the manuscript and revised the manuscript. AL revised the manuscript. All authors have given approval for the final version to be published.

Competing interests

The authors declare that they have no competing interests.

\section{Consent for publication}

A written informed consent was obtained from the patient for publication of this case report and any accompanying images.

Ethics approval and consent to participate

Not applicable.

\section{Author details}

${ }^{1}$ Institute of Pathology, Medical University of Graz, Graz, Austria. ${ }^{2}$ Department of Orthopedics and Orthopedic Surgery, Medical University of Graz, Graz, Austria.

Received: 5 May 2016 Accepted: 11 August 2016

Published online: 18 August 2016

\section{References}

1. Swerdlow SH, Campo E, Harris NL, Jaffe ES, Pileri SA, Stein H, Thiele J, Vardiman JW. WHO Classification of Tumours of Haematopoietic and Lymphoid Tissue, 4th Edition. Lyon, France: IARC Press; 2008.

2. Chaudhry MS, Mather $H$, Marks A, Naresh K. Diffuse large B cell lymphoma complicating total knee arthroplasty: case report and literature review of the association of diffuse large B cell lymphoma with joint replacement. Acta Haematol. 2011;126(3):141-6. doi:10.1159/000328202.

3. Friedberg JW, Fisher RI. Diffuse large B-cell lymphoma. Hematol Oncol Clin North Am. 2008;22(5):941-52. doi:10.1016/j.hoc.2008.07.002. ix.

4. Tong MY, Zhang X, Yu Z, Sun XH, Li S, Zhang Y. Primary sternum diffuse large B-cell lymphoma: a case report and review of the literature. Oncol Lett. 2015;9(6):2623-8. Epub 2015 Apr 16.

5. Campo E, Swerdlow SH, Harris NL, Pileri S, Stein H, Jaffe ES. The 2008 WHO classification of lymphoid neoplasms and beyond: evolving concepts and practical applications. Blood. 2011;117(19):5019-32. doi:10.1182/blood-201101-293050. Epub 2011 Feb 7.

6. Romero-Rojas AE, Diaz-Perez JA, Raju S, Messa-Botero O, Prieto-Bletan A, Criollo-Palacios F. Primary diffuse large B-cell lymphoma associated with chronic osteomyelitis of the knee. Knee. 2014;21(6):1280-3. doi:10.1016/j. knee.2014.08.016. Epub 2014 Sep 8.

7. Sanchez-Gonzalez B, Garcia M, Montserrat F, Sanchez M, Angona A, Solano A, Salar A. Diffuse large B-cell lymphoma associated with chronic inflammation in metallic implant. J Clin Oncol. 2013;31(10):e148-51. doi:10. 1200/JCO.2012.42.8250. Epub 2013 Feb 11.

8. Cheuk W, Chan AC, Chan JK, Lau GT, Chan VN, Yiu HH. Metallic implantassociated lymphoma: a distinct subgroup of large B-cell lymphoma related to pyothorax-associated lymphoma? Am J Surg Pathol. 2005;29(6):832-6.

9. Eskander MS, McPhee E, Eskander JP, Nascimento R, McCormick JJ, Hao S, Shepro D, Johnson K. A left knee wound complication by non-Hodgkins lymphoma in bilateral total knee arthroplasties. Arch Orthop Trauma Surg. 2008;128(12):1387-90. doi:10.1007/s00402-008-0568-z. Epub 2008 Jan 23.

10. Ganapathi M, Lake DN, Griffiths AP. Periprosthetic high-grade B-cell lymphoma complicating an infected revision total hip arthroplasty. J Arthroplasty. 2001;16(2):229-32.

11. O'Shea K, Kearns SR, Blaney A, Murray P, Smyth HA, McElwain JP. Periprosthetic malignancy as a mode of failure in total hip arthroplasty. J Arthroplasty. 2006;21(6):926-30.

12. Radhi JM, Ibrahiem $\mathrm{K}$, al-Tweigeri T. Soft tissue malignant lymphoma at sites of previous surgery. J Clin Pathol. 1998;51(8):629-32.

13. McDonald I. Malignant lymphoma associated with internal fixation of a fractured tibia. Cancer. 1981;48(4):1009-11.

14. Ladon D, Doherty A, Newson R, Turner J, Bhamra M, Case CP. Changes in metal levels and chromosome aberrations in the peripheral blood of patients after metal-on-metal hip arthroplasty. J Arthroplasty. 2004;19(8 Suppl 3):78-83. 
15. Gross A, Joller-Jemelka HI, Wicki AN, Grob PJ. Hepatitis serological finding "anti-HBC alone", circulating viral DNA and interpretation of findings. Schweiz Med Wochenschr. 1993;123(23):1193-202.

16. Ulcickas Yood M, Quesenberry Jr CP, Guo D, Caldwell C, Wells K, Shan J, Sanders L, Skovron ML, lloeje U, Manos MM. Incidence of non-Hodgkin's lymphoma among individuals with chronic hepatitis B virus infection. Hepatology. 2007;46(1):107-12.

17. Abe SK, Inoue M, Sawada N, Iwasaki M, Shimazu T, Yamaji T, Sasazuki S, Tanaka Y, Mizokami M, Tsugane S, JPHC Study Group. Hepatitis B and C virus infection and risk of lymphoid malignancies: a population-based cohort study (JPHC Study). Cancer Epidemiol. 2015;39(4):562-6. doi:10.1016/ j.canep.2015.06.002. Epub 2015 Jul 3.

18. Deng L, Song Y, Young KH, Hu S, Ding N, Song W, Li X, Shi Y, Huang H, Liu W, Zheng W, Wang X, Xie Y, Lin N, Tu M, Ping L, Ying Z, Zhang C, Sun Y, Zhu J. Hepatitis B virus-associated diffuse large B-cell lymphoma: unique clinical features, poor outcome, and hepatitis B surface antigen-driven origin. Oncotarget. 2015;6(28):25061-73. doi: 10.18632/oncotarget.4677.

19. Wang F, Xu RH, Han B, Shi YX, Luo HY, Jiang WQ, Lin TY, Huang HQ, Xia ZJ, Guan ZZ. High incidence of hepatitis B virus infection in B-cell subtype nonHodgkin lymphoma compared with other cancers. Cancer. 2007;109(7):1360-4.

20. Dalia S, Chavez J, Castillo JJ, Sokol L. Hepatitis B infection increases the risk of non-Hodgkin lymphoma: a meta-analysis of observational studies. Leuk Res. 2013;37(9):1107-15. doi:10.1016/j.leukres.2013.06.007. Epub 2013 Jun 26.

21. Nath A, Agarwal R, Malhotra P, Varma S. Prevalence of hepatitis B virus infection in non-Hodgkin lymphoma: a systematic review and meta-analysis. Intern Med J. 2010;40(9):633-41. doi:10.1111/j.1445-5994.2009.02060.x.

\section{Submit your next manuscript to BioMed Central and we will help you at every step:}

- We accept pre-submission inquiries

- Our selector tool helps you to find the most relevant journal

- We provide round the clock customer support

- Convenient online submission

- Thorough peer review

- Inclusion in PubMed and all major indexing services

- Maximum visibility for your research

Submit your manuscript at www.biomedcentral.com/submit

C) Biomed Central 